\title{
No Pottery at the Western Periphery of Europe: why was the final Mesolithic of Britain and Ireland aceramic?
}

\author{
Ben Elliott ${ }^{1}$, Aimée Little ${ }^{2}$, Graeme Warren ${ }^{1}$, Alex Lucquin², Ed Blinkhorn ${ }^{3}$, Oliver E Craig ${ }^{2}$ \\ 1 - School of Archaeology, University College Dublin, Belfield, Dublin, Dublin 4, IE \\ 2 - Department of Archaeology, University of York, Heslington, York, YO10 5DD, UK \\ 3 - Institute of Archaeology, University College London, London, WC1E 6BT, UK
}

The past decade has witnessed an intensification of research into hunter-gatherer pottery. Long viewed by Western scholars as a marginal activity, pottery production is now known to be widespread among prehistoric hunter-gatherers with no demonstrable link to agriculture. However, in emphasising the centrality of ceramics to these communities, we often risk marginalising hunter-gatherers who did not adopt pottery. Here, we critically examine a series of different models proposed for hunter-gatherer pottery innovation and adoption, within the context of the aceramic hunter-gathering communities who inhabited the Britain and Ireland during the 5th millennium cal. BC.

\section{Introduction}

The Irish and British Mesolithic is traditionally characterised as aceramic. Evidence for the use of pottery vessels is absent within their respective Pleistocene and Early Holocene archaeological records, with the earliest pottery exclusively linked to the few centuries of change associated with the arrival of agriculture c.4100-3800 cal. BC (Whittle et al. 2011). Whilst regional research has stressed the differences between human behaviour and environmental conditions in Britain and Ireland (Warren 2015; Woodman 2015), this shared aceramicism has often gone overlooked within frameworks of research which assume pottery to be an a priori facet of Neolithic life. This becomes particularly acute within the $5^{\text {th }}$ millennium cal. BC; a period of time in which both the agrarian and hunter-gatherer communities around the North Sea Basin and Atlantic façade were producing pottery on a grand scale. Why then was this technology not adopted by hunter-gatherers living in Britain and Ireland? 


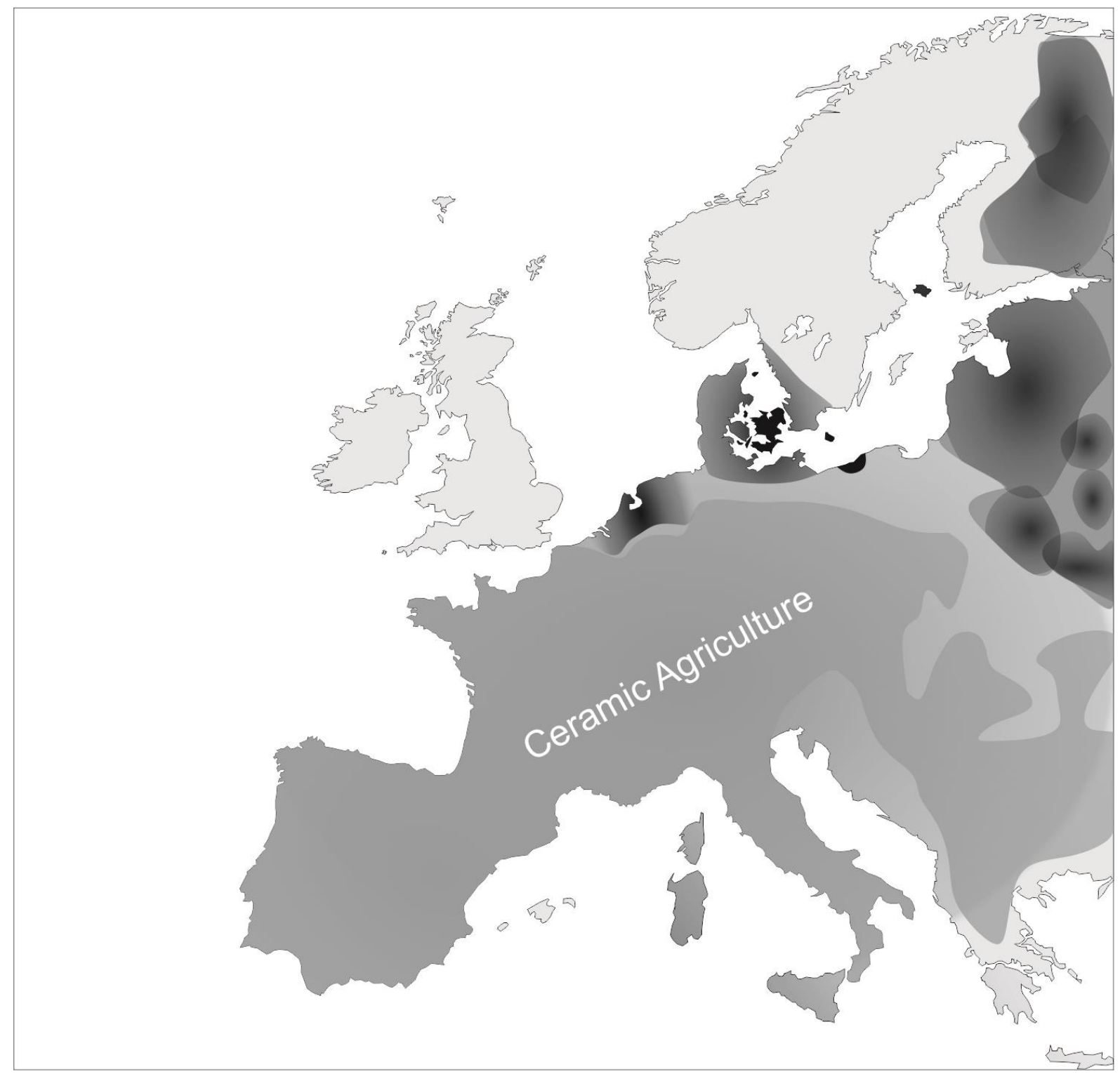

Figure 1.

\section{Pottery within hunter-gatherer societies}

The obvious answer to this question is that hunter-gatherers did not need pottery. Whilst ceramic technology has been long associated with prehistoric farmers and the 'Neolithic package', it is now clear that pottery was produced by range of prehistoric hunter-gatherers (Jordan and Zvelebil 2009). In fact, the very first ceramic containers emerged among East Asian hunter-gatherers during the Late Pleistocene at sites in Southern China (c.16,000 BC), the Russian Far East, and Japan (c.14,000 BC) (Yanshina 2017). In East Asia, pottery production dramatically increased at the start of the Holocene as it assumed a broader role in food preparation (Lucquin et al. 2018). Pottery is first recorded on hunter-gatherer sites east of the Ural mountains at c.7,000 cal BC and in the Baltic by $5,500 \mathrm{cal} \mathrm{BC}$ (Piezonka 2015). During the late 6 th and 5 th millennia BC, hunter-gatherer pottery was produced in large quantities in the Low Countries (Swifterbandt), Northern Germany and Denmark (Ertebølle), and possibly Northern France (LaHougette/Limburg). 
Further evidence from North America, North and West Africa and the Arctic reinforces that ceramic-using hunter-gatherers were far from exceptional (Jordan \& Zvelebil 2009). Pottery was favored by hunter-gatherers living within at rich aquatic ecotones, and residue analysis of hunter-gatherer ceramics from sites across the globe indicates their role in processing aquatic foods. The specific role of pottery within these contexts is debated; it has been suggested to have been used in to render oils for storage and accumulation (Taché \& Craig 2015) and/or as a prestige technology implicated in feasting (Hayden 1995). However, pottery appears to have been produced in anticipation of high returns from predictable gluts of aquatic resources.

Evidently, these were socially structured groups inhabiting rich environments, following delayed returned economic models. They did not live on ecological margins or on an 'inevitable trajectory' to farming, as sometimes supposed. Furthermore, pottery was repeatedly invented by foragers, thus, was not a technology universally acquired from adjacent farming groups, as often assumed by prehistorians. As such, research questions now focus on why some took up this technology and not others. This paper explores precisely this question by examining a range of explanations for apparent absence of ceramics in 5th millennium cal BC Ireland and Britain. These draw from current archaeological and anthropological scholarship on ceramic adoption within hunter-gatherer societies; the strength of each position will be assessed in relation to the archaeological record.

\section{"Ceramic technologies were not adopted because there was no contact between Britain and Ireland during the 5th millennium cal. BC"}

The supposed "cultural isolation" of Britain and Ireland during their respective Late Mesolithic periods has been used as an explanation for both the absence of the trapezoidal microlith forms by 6500 BC (Jacobi 1976) and the delayed adoption of agriculture (Sheridan 2010). If pottery dispersed via contact between neighbouring hunter-gatherer communities (Jordan \& Zvelebil 2009: 74) a lack of communication between people in Ireland, Britain, and their pottery-producing counterparts along the North Sea coast and Atlantic Façade, might help explain the absence of ceramics.

This argument is, however, difficult to substantiate within the archaeological record. A history of contact between Mesolithic Britain and Mainland Europe stretches back into the Early Holocene when lower sea levels allowed people to move across Doggerland (Gaffney et al. 2009), with material culture and settlement patterns echoing those seen elsewhere in both Northern and Atlantic Europe (Sørensen et al. 2018; Warren 2015). Despite the transformation of Doggerland into a series of archipelagos, the occurrence of hollow-based microlith forms within Southern Britain and Northern France during the French Middle Mesolithic (Ghesquiére 2012) suggests that inundation did not sever these links. Synchronicity between the Irish Early/Late Mesolithic and French "premiere/seconde" transitions have been noted (Costa \& Marchand 2006) and may indicate a cultural dialogue between these regions at 7000-6000 cal. BC (Warren 2015). This suggests a significant history of contact between Britain, Ireland, and mainland Europe, prior to $5000 \mathrm{cal}$. BC. 


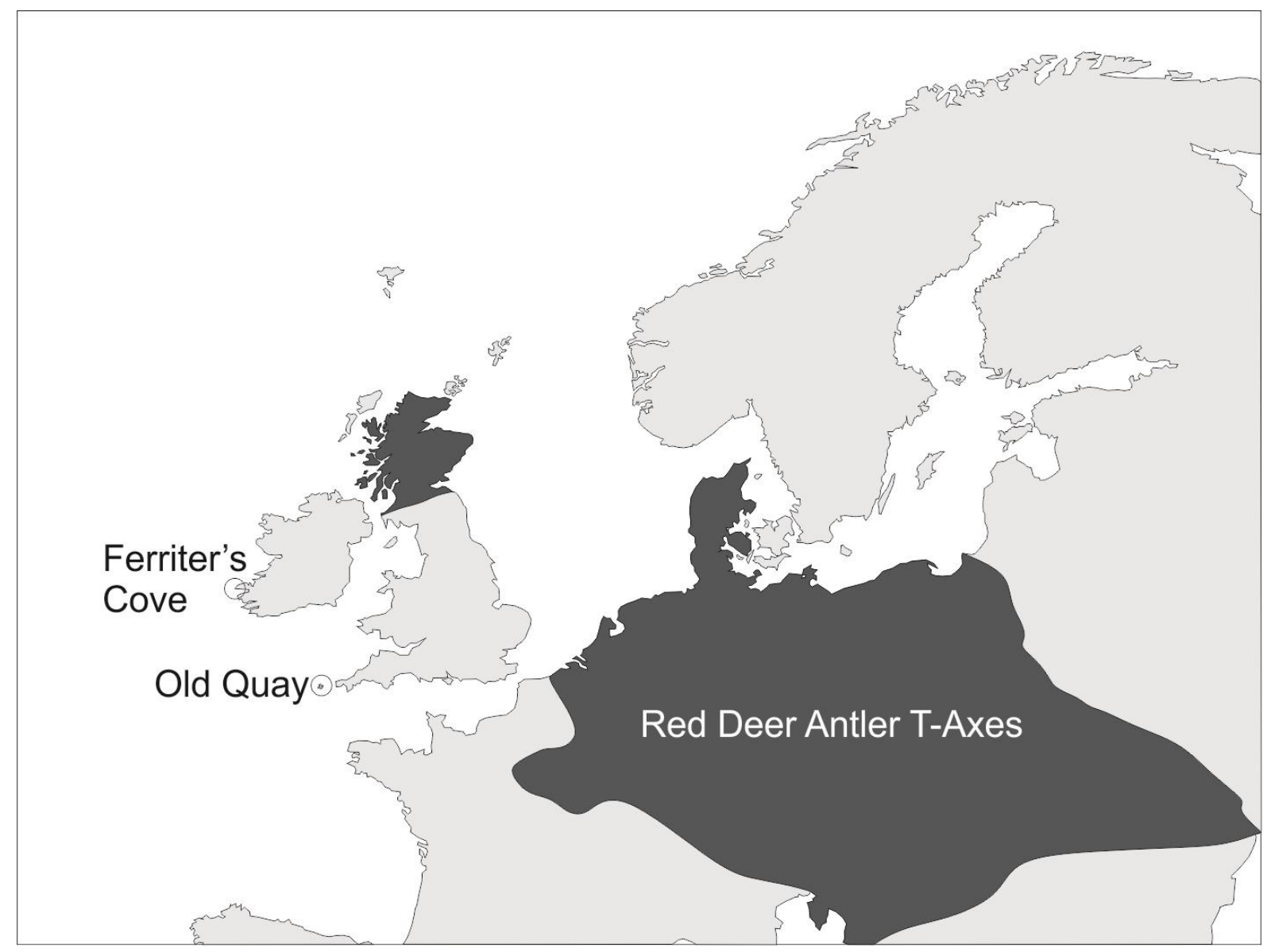

Figure 2.

Whilst specific commonalities fade following the final inundation of Doggerland (Sturt et al. 2013), the spread of red deer antler T-axes around the North Sea Basin (Elliott 2015) clearly demonstrates that exchange of ideas continued. The earliest T-axe dates from Scotland predate those of the Ceramic Ertebølle by several hundred years. Therefore, if $\mathrm{T}$-axes represent a technological concept originating from agricultural groups in Central Europe (Stapel et al. 2012), these were adopted more rapidly in Western and Eastern Scotland than in Southern Scandinavia. The presence of an unusual trapezoidal/transversal microlith assemblage at Old Quay, Isles of Scilly (Anderson-Whymark et al. 2015), with loose typological affinities to 5th millennium BC microlith production in Northern France and Belgium (Crombé 2015), further suggests movement of people between Southern Britain and the Low Countries. Repeated reoccupation at New Quay indicates that these contacts persisted for a considerable period of time (Sturt \& Garrow 2017: 131).

Evidence for contact between Ireland and mainland Europe is varied. The modern Irish Cepea nemoralis, (terrestrial Brown-lipped snail) shares haplotypes with Pyrenean or Cantabrian Cepea nemoralis but not French or British. This has been suggested to indicate direct contact facilitating the importation of the species during the late 8th/early 7 th millennium cal. BC (Carlsson et al. 2014). Warren's (2015) review of technological developments in Brittany and Ireland proposes links during the Late Mesolithic. Finally, contact between Ireland and mainland Europe in the 5th millennium is definitively demonstrated by the appearance of domesticated cattle bones in Late Mesolithic contexts at Ferriter's Cove, County Kerry (Woodman et al. 1999). 
Therefore, whilst the 5th millenium archaeological record of Britain and Ireland is distinct to that of Continental Europe, there is now tangible evidence for the continuity of the connections which characterised the earlier Mesolithic. People in Britain and Ireland were in contact with their pottery producing neighbours from c.5000 cal BC onwards.

"Britain and Ireland lack the optimum environmental conditions for pottery adoption" The early emergence of ceramic technologies has been linked to the productivity of specific environment types (Brown 1989). This is supported by the association of incipient huntergatherer pottery in Japan with the exploitation of rich marine ecotonal resources (Craig et al. 2013). However, there is strong evidence of inhabitation of similar environments during the 5th millennium cal BC across Britain and Ireland. Intertidal zones were visited throughout the Mesolithic in Western Britain (Bell 2007), West Scotland (Bonsall 1996), and coastal Ireland (Kador 2010). Late Mesolithic Ireland is traditionally characterised by a focus on inland waterway systems, mapping onto these aquatic ecotones (Little 2014). Occupation at coastal sites is often characterised by the presence of shell middens (Finlay et al. 2019), indicating exploitation of marine and intertidal resources associated with the adoption of pottery by hunter-gatherers elsewhere.

\section{"Hunter gatherers in Britain and Ireland lacked the "economic affluence" to necessitate ceramics"}

Early pottery research also suggests a link between economically affluent hunter-gatherers and the adoption of ceramic technologies: proposing a major role for pottery to processes surplus to create storable commodities (Hayden 1995; Jordan \& Zvelebil 2009). Given the fundamentally relative nature of surplus production, its reliance on the quantities of resources collected and the demand for the resource itself, it is notoriously difficult to demonstrate material affluence within the archaeological record (Kuijt 2009). The coastal and lacustrine settlement patterns noted above offered the opportunity to exploit a range of resources in large volumes within Britain and Ireland during the 5th millennium cal. BC.

Some aspects of the Irish Later Mesolithic, including fence and wattle-work coppiced basket fish traps from Clowanstown (5320-4720 cal BC) indicate the technological capacity to create seasonal surplus (Mossop 2009). Pit digging, potentially indicative of storage, is welldocumented throughout the Mesolithic of Britain and Ireland (Blinkhorn et al. 2017). The archaeological record therefore indicates that Mesolithic people had the ecological and technological potential to acquire material resources on a large-scale, despite the difficulties in categorically identifying "surplus" within the archaeological record.

\section{"Low population densities in Britain and Ireland prevented the spread of new technologies generally"}

During the Late Pleistocene in Japan, pottery was only produced only in very low numbers (Taniguchi 2017). Kaner (2009) argues that this is due to hunter-gatherers being dispersed into small and isolated groups, who lacked the ontological security required to invest in intensive production. Hunter gatherers in Britain and Ireland may have faced similar ontological inhibitors if living in dispersed, low density populations where the novel concepts of making and using pottery were not reinforced by 'normative' behaviour. Three distinct approaches to estimating population density have been applied to the Irish and British 
Mesolithic based on frequency of radiocarbon dates, aDNA analysis and models formed from ethnographic demography data.

The 5th millennium cal BC Britain has relative few robustly dated "site phases" compared to later prehistoric periods in Britain. This has been interpreted as evidence for a relatively low population inhabiting Britain during the Late Mesolithic (Collard et al. 2010). However, analysis of the archaeological data is fundamentally problematic: the character of Neolithic behaviour is intrinsically more likely to produce recognisable "site phases" and associated radiocarbon dates (Blinkhorn and Milner 2014). Environmental change and variation in human behaviour influence the quantities of dated archaeological contexts. For example, the hazel rise providing the ubiquitous charred hazel shells on which British Mesolithic chronologies rely and the practice of stone-lined hearth construction provides dates in the Late Mesolithic (Griffiths 2014). Neolithic dates often originate from domesticated animal bones or preserved human remains, the former being absent and the later extremely rare within 5th millennium cal BC Britain, and thus leave this period under represented. Similar factors affect the archaeological record of Late Mesolithic Ireland where, despite the widespread distribution of typologically "Late Mesolithic" lithics dating to c.6000-4000 cal BC, very few sites have produced stratigraphically linkable radiocarbon dates (Warren In Press) . The Mesolithic is thus disproportionately underrepresented within radiocarbon datasets. Therefore, whilst these studies highlight the potential for a low population in the Late Mesolithic of Britain and Ireland, it remains to be conclusively demonstrated.

The strongest evidence for low population densities prior to the arrival of farming in Britain comes from Mesolithic, Neolithic and Bronze Age aDNA (Brace et al. (2019). Put simply, the degree of hunter-gatherer genetic ancestry within later Neolithic groups of Britain is lower than would be expected if a large population of hunter-gatherers had inhabited Britain during the 5th millennium cal BC, as appears to be the case in other areas of continental Europe (eg Olalde et al. 2018). Similarly, the genetic evidence from Britain points towards a different scenario to that observed in Southern Sweden, where aDNA analysis has shown genetic continuity between ceramic using hunter-gatherers (i.e. Ertebolle to Pitted Ware) well beyond the arrival of Neolithic populations and farming (Skoglund et al. 2014). This pattern has been interpreted as evidence for a large resilient indigenous population, albeit one that went through cultural change. The emerging aDNA evidence of course provides only comparative insights into population sizes and is not a direct measure, factors other than population size, such as selection, behaviour and outward migration would have a bearing. We are also still far from converting observations of contrasting population dynamics to any comparable census data. Nevertheless, the genetic history of Britain during this period seems atypical in the wider European context.

In contrast, attempts to predict the size of hunter-gatherer populations using ethnographic data contradicts the idea that Britain and Ireland were sparsely populated during the Late Mesolithic. Tallavaara et al (2018) used a range of variables including mean annual climate, mammal, bird and vascular plant richness, and pathogen risks, alongside ethnographic data concerning hunter-gatherer population densities to model global carrying capacities for hunter-gatherer societies. This model suggests that Britain and Ireland had the potential to sustain relatively dense populations - as dense, if not morso than other regions of Europe where pottery was produced. 


\section{"Pre-existing cooking and container technologies were deemed superior to ceramics in Britain and Ireland"}

Whilst ceramic containers allow for the storage, cookery and presentation of resources within hunter-gatherer societies, aceramic forms of container technologies share many of these functional attributes. It is possible that pottery offered no discernible benefit to the communities of 5th millenium BC Ireland and Britain. In Ireland, evidence for hunter-gatherer cooking technology can be considered relatively rich and varied. The pot boiler cooking method has been suggested for the riverine and terminal Late Mesolithic site of Clonava (Little 2014); storage and cooking of plants in pit and hearth features is known from Mesolithic contexts (c.5500-3900 cal BC) at nearby Derragh, Lough Kinale (McGlynn et al. 2018). The preservation of Late Mesolithic fish traps provide direct evidence for basket technologies. No Mesolithic basket containers have yet been found in Britain, though early container technology is evidenced by a large wooden vessel from recent excavations at Star Carr (Taylor et al. 2018). Microwear analysis of blades from British and Irish Mesolithic sites has revealed similarities with Continental assemblages where transverse plant working traces appears particularly prevalent in Holocene hunter-gatherer assemblages (van Gijn and Little 2016). It has been suggested that these traces may be the result of lithic tools being used in the manufacture of plant-derived container technologies and may account for why these traces disappear when agriculture takes hold in the Rhine Meuse Delta region (A. Little \& van Gijn 2017). An absence of other non-plant-derived hunter-gatherer container technologies, e.g. animal skins/stomachs, known from ethnography (eg Sturm et al. 2016), means we can only speculate on how widespread the use of these materials as storage and cooking vessels was in Mesolithic Britain and Ireland. Irrespective of this, it is unlikely that aceramic container technologies - whether plant or animal derived - were vastly different or superior in Britain and Ireland to that used in regions where pottery was adopted by huntergatherers.

\section{"Mesolithic populations in Britain and Ireland were too mobile for pottery"}

Global ethnographic reviews investigating the relationship between ceramic use and mobility levels posit that ceramic production is inherently linked to sedentism due to the cumbersome nature of pottery (Arnold 1985). This raises the possibility that differences in mobility between hunter-gatherers living in Britain, Ireland and adjacent areas of continental Europe, may be linked to the differential uptake of ceramics across these regions.

There exists a number of problems with both the anthropological grounding and archaeological application of this idea, making it difficult to substantiate within the context of the 5th millennium cal BC. Despite large-scale ethnographic patterns, there are numerous historically documented instances of aceramic, sedentary hunter-gatherers and ceramic, mobile hunter-gatherers (Eerkens 2003; Bright \& Ugan 1999). Notions of residential/logistical mobility and the seasonal round have been soundly critiqued within both anthropology and the Mesolithic of Britain and Ireland (Spikins 2000; Preston and Kador 2018; Kelly 1995). The only reliable case study on very late 5 th millennium cal. BC mobility in Britain comes from Oronsay, Inner Hebrides. Here, stable isotope evidence (Charlton et al. 2016) and settlement patterns (Finlay et al. 2019) suggest regional mobility between islands and the Scottish coast. Currently it is not possible to establish a relationship between mobility and ceramic use within hunter gatherer studies on theoretical or empirical grounds. There seems to be little evidence for differences in mobility between the archaeologies of British and Irish Mesolithic sites compared to contemporary sites in the Netherlands or Denmark. 
Caution should be exerted when using this small sample to extrapolate mobility patterns across Ireland and Britain. We currently have little archaeological data to model 5th millenium BC mobility; given the outstanding questions concerning the relationship between mobility and ceramic use within hunter gatherer anthropology, neither the theoretical nor archaeological validity of this argument are currently demonstrable.

"The maritime character of connections played an active role in the pottery dispersal" At the continental scale, one striking difference between Ireland, Britain and the other contexts in which ceramic technologies were spread, is their island character. Considerable bodies of water separated the aceramic hunter-gatherer communities of Britain and Ireland from their pottery-using neighbours. Whilst the evidence for contact between these groups during the 5th millennium BC is discussed above, the role that maritime journeys across the North Sea Basin and Western Seaway may have played in inhibiting the adoption of ceramics has seldom been considered. In order to better understand the extent to which these specific forms of contact influence the spread of ceramics between hunter-gatherer groups in Europe, it is worth considering their dispersal across other European island systems.

Two themes emerge from a review of pottery adoption on European islands. Firstly, there is no evidence for hunter-gatherer innovation of ceramic technologies on any of these landmasses. In the case of Åland, ceramic technologies were developed elsewhere and vessels imported from mainland contexts by visiting hunter-gatherers (Jordan and Zvelebil 2009). Secondly, on Sardinia (Dyson and Rowland 2007), Cyprus (Vigne et al. 2011), Crete (Cherry 1981), and Gotland (Lindqvist and Possnert 1999), pottery adoption is often seen alongside the arrival of agricultural practices and classically "Neolithic" archeological signatures. However, unlike Britain and Ireland, the spread of both pottery and agriculture does not appear to be delayed by the nature of the maritime journeys required to bring these practices to island contexts. Neither the challenges of seafaring, nor the pre-existing inhabitants of these islands, appear to have contributed to a similar "delay" in the adoption of pottery or agriculture as seen in Britain and Ireland. Thus, there is nothing inherent within the character of Mesolithic maritime journeying which inhibits the transmission of ceramic technologies to island communities.

\footnotetext{
"Mesolithic pottery exists in Ireland and Britain, we have just failed to recognise it" Another explanation is the possibility that this material does exist but has not been recognised by archaeologists. Rocek (2013) argues that the archaeological signatures of pottery adoption may involve an initial 'software horizon' within which pottery may be fragile and inconsistent in form. However, given that continental 5th millennium pottery-using hunter-gatherer groups produced easily identifiable sherds, following this model implies that any small-scale ceramic experiments undertaken in Britain and Ireland were fundamentally different to the production of pottery elsewhere in Europe.
}

Occasional rumours surface of ceramics in association with Mesolithic sites in Britain and Ireland, but have yet to be publically substantiated. It is unlikely that pottery is being misidentified at the increasing number of Late Mesolithic sites excavated by commercial archaeological units where excavators have much more experience in identifying this material than Mesolithic specialists. Mesolithic sites in Ireland and Britain have not produced 
any ceramics to date. It therefore seems unlikely that this reflects biases within archaeological practice.
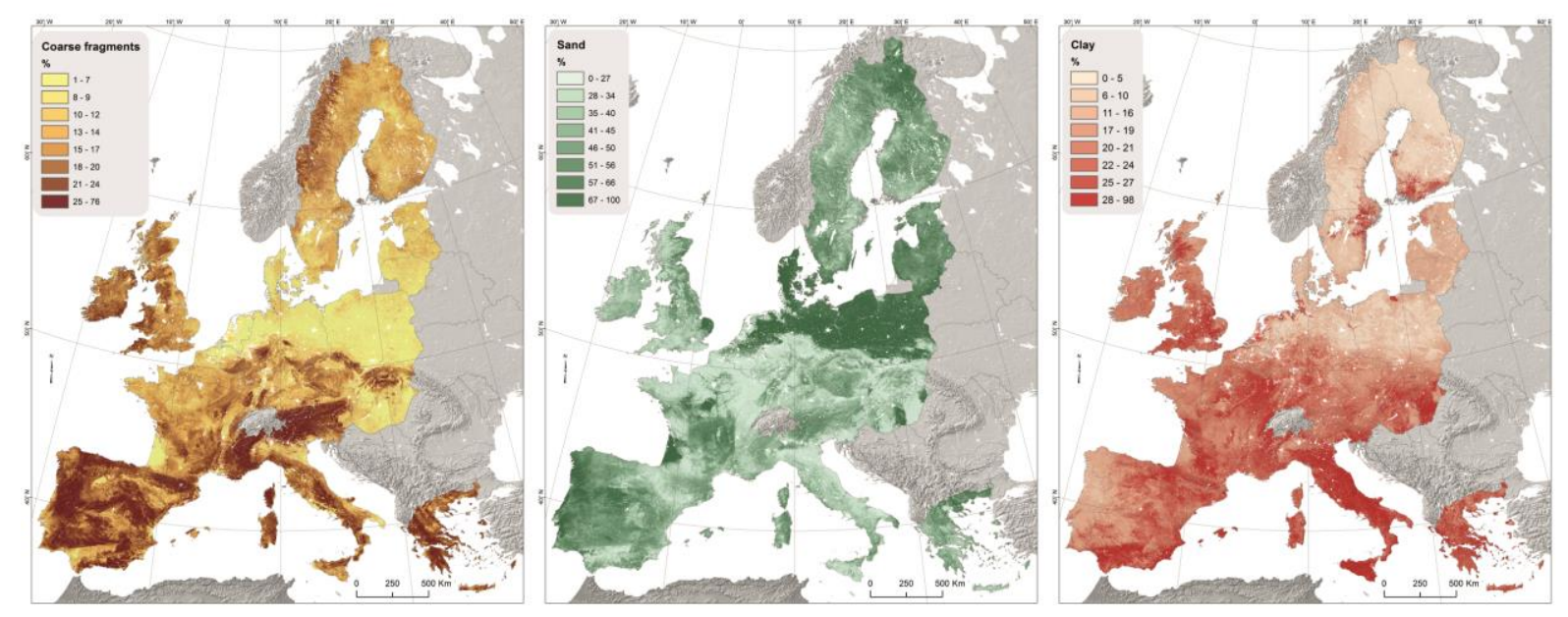

Figure 3.

\section{"The raw materials needed to make pottery were less available in Britain and Ireland compared to other areas of Europe"}

A final, previously undiscussed, explanation for the lack of pottery in 5th millenium BC Ireland and Britain is the availability of raw materials for the ceramic technologies used by contemporaneous hunter-gatherer groups. Cover sediment characterisation data indicates differences between the composition of areas in which pottery was adopted by huntergatherer groups and Britain and Ireland (Figure 3). Areas which see the adoption of Swifterband, Ertebølle, Sperrings, and Early Comb wares are characterised by low clay/high sand content, and low coarse fragments within their cover sedimentology. In contrast, Britain and Ireland can generally be characterised by high clay/low sand, and variable coarse fragment compositions. Significant differences at the macroscopic scale in present day sediment composition exist therefore between areas of Europe where hunter-gatherers adopted ceramic technologies during the 5th millennium BC and areas where they did not. Historical biases in site distributions whereby clay geologies were presumed to be suboptimal for British Mesolithic habitation are slowly being overturned by survey work, though substantial lacunae still exist. Both Britain and Ireland evidently have widespread sediments suitable for pottery but different patterns of Mesolithic occupation, whatever they might be, across changing surface geologies may coincide with divergent relationships with and opportunities within the landscape.

Interpretation of this data is complicated by the ability of farming societies in other regions of Europe to produce pottery in sedimentary conditions similar to that of Ireland and Britain. However, the pottery in farming societies at this time is heavily focussed on milk storage. Ceramic technologies associated with farming groups may have been perceived as irrelevant by non-dairying hunter-gatherers. While the coarse scale of these sediment maps presents issues of resolution, the relationship between Early/Mid Holocene and present day sediment cover requires further investigation to better understand the spread of ceramic technologies across Northern Europe at this time. 


\section{Conclusion}

Other than a possible difference in cover soil composition, the environmental and ecological conditions would appear to be similar to Baltic and North Sea coasts of continental Europe, including their offshore islands, where pottery was readily adopted and widely used. Social and demographic explanations must therefore be invoked. Although capable of supporting large numbers of hunter-gatherers, the low degree of hunter-gatherer ancestry recorded in the DNA of Neolithic British individuals would appear to preclude a high population density during the late Mesolithic. This interpretation is supported by crude population assessments made by considering relative numbers of radiocarbon dates in different periods. While both these measures are indirect and faliable, an argument can be made that the relative population density was key to the transmission of pottery.

Contact with contiental Europe, shown by other forms of material culture, suggests that hunter-gatherers in Britain probably had knowledge of ceramic technology. However, knowledge of a technology's existence does not directly equate to its adoption. Adoption requires changes in attitude and behaviour which are underpinned by concepts of relative technological merit (e.g. assessment of relative performance, risk and cost) (Ajzen 1991). Such concepts might include perceived barriers or incentives regarding pottery production and use (control beliefs), social pressures regarding the merits or inferiority of pottery technology (normative beliefs), or prior beliefs in the advantages/disadvantages of pottery technology (behavioral beliefs).

Sociodemography is clearly relevant to the transmission of these concepts. As Kaner (2009) notes for the Jomon, pottery production did not become normalised behaviour until the population dynamics, in terms of size and connectivity, allowed key concepts of production and use to be shared and reinforced. A similar, synchronous population density increase and shift in exchange networks is observed with the adoption of Early Comb Ware in Finmark (Damm et al. 2019). It seems plausible that the networks connecting island and continental Europe were insufficient in the 5th millenium BC to provide British and Irish hunter-gatherers the forms of contact required to facilitate the necessary conceptual shifts to start producing pots. These populations were clearly exchanging ideas, yet this contact was evidently not in a form that would allow the transmission of ceramic technologies specifically. As such, the inhabitants of 5th millenium Britain and Ireland lacked salient beliefs in the efficacy of the pottery against competing technologies for preparing and storing foods and other natural products. Neolithic farmers arriving in Britain and Ireland at the start of the next millennium faced no such inhibitions of course: pottery had been firmly embedded in their technological repertoire and part of their worldview for many previous generations.

Given the emergent body of research demonstrating contact between Britain, Ireland and continental Europe during the 5th millennium cal. BC and the well documented widespread use of pottery by hunter-gatherers in other regions of Northern Europe at this time, the question of why pottery was not adopted in Britain and Ireland becomes particularly pertinent for Mesolithic research. This represents an advancement for conceptualisations of the period, where the absence of the classic components of the "Neolithic" package has hitherto remained unquestioned. The process of pottery adoption is no longer a concern reserved exclusively for Neolithic archaeology in Europe. 


\section{Acknowledgements}

This paper stems from an invited contribution to the Early Pottery Research Group Meeting in York, 2017 and was supported by the ERC Advanced Grant INDUCE (ERC-2015-AdG, 695539).

\section{$\underline{\text { References }}$}

Ajzen, I., 1991. The theory of planned behavior. Organizational behavior and human decision processes, 50(2), pp.179-211.

Anderson-Whymark, H., Garrow, D. \& Sturt, F., 2015. Microliths and maritime mobility: a continental European-style Late Mesolithic flint assemblage from the Isles of Scilly. Antiquity, 89(346), pp.954-971.

Arnold, D., 1985. Ceramic Theory and Cultural Process, Cambridge: Cambridge University Press.

Bell, M., 2007. Prehistoric Coastal Communities: The Mesolithic in western Britain, York: Council for British Archaeology.

Blinkhorn, E., Lawton-Matthews, E. \& Warren, G., 2017. Digging and filling pits in the Mesolithic of England and Ireland: comparative perspectives on a widespread practice. In N. Achard-Corompt, E. Ghesquière, \& V. Ruquier, eds. Creuser au Mésolithique/Digging in the Mesolithic. Actes de la séance de la Société préhistorique française Châlons-en-Champagne 29-30 mars 2016. Paris: Société Préhistorique Française, pp. 211-224.

Blinkhorn, E. \& Milner, N., 2014. Mesolithic Research and Conservation Framework, York: Council for British Archaeology.

Bonsall, C., 1996. The "Obanian problem": coastal adaptation in the Mesolithic of western Scotland. In T. Pollard \& A. Morrison, eds. The Early Prehistory of Scotland. Edinburgh: Edinburgh University Press, pp. 183-197.

Brace, S. et al., 2019. Ancient genomes indicate population replacement in Early Neolithic Britain. Nature ecology \& evolution, 3, pp. 765-771.

Bright, J. \& Ugan, A., 1999. Ceramics and mobility: Assessing the role of foraging behavior and its implications for culture history. Utah Archaeology, 12, pp.17-30.

Brown, J., 1989. The beginnings of pottery as an economic process. In S. van der Leeuw \& R. Torrence, eds. What's New? A Closer Look at the Process of Innovation. London: Unwin Hyman, pp. 203-224.

Carlsson, J. et al., 2014. The use of genetics to infer the origins of the terrestrial and freshwater elements of the Irish fauna. The Irish Naturalists' Journal, 33, pp.8-27.

Charlton, S. et al., 2016. Finding Britain's last hunter-gatherers: A new biomolecular approach to "unidentifiable" bone fragments utilising bone collagen. Journal of Archaeological Science, 73, pp.55-61.

Cherry, J., 1981. Pattern and Process in the Earliest Colonization of the Mediterranean Islands. Proceedings of the Prehistoric Society, 47, pp.41-68.

Collard, M. et al., 2010. Radiocarbon evidence indicates that migrants introduced 
farming to Britain. Journal of Archaeological Science, 37(4), pp.866-870.

Conneller, C. et al., 2018. The Worked Flint. In N. Milner, C. Conneller, \& B, Taylor, eds. Star Carr Volume 2: Studies in Technology, Subsistence and Environment. York: White Rose University Press, pp. 493-534.

Costa, L. \& Marchand, G., 2006. Transformations des productions lithiques du premier au second Mésolithique en Bretagne et en Irland. Bulletin de la Société Préhistorique Francaise, 103, pp.275-290.

Craig, O. et al., 2013. Earliest evidence for the use of pottery. Nature, 496, p.351.

Crombé, P., 2015. The "microliths" from the Isles of Scilly and the continental Mesolithic: similar yet still so different. Antiquity, 89(346), pp.980-981.

Damm, C. et al., 2019. Investigating long-term human ecodynamics in the European Arctic: Towards an integrated multi-scalar analysis of early and mid Holocene cultural, environmental and palaeodemographic sequences in Finnmark County, Northern Norway. Quaternary international, https://doi.org/10.1016/j.quaint.2019.02.032

Dyson, S. \& Rowland, R., Jr., 2007. Archaeology and History in Sardinia from the Stone Age to the Middle Ages: Shepherds, Sailors, and Conquerors. Pennsylvania: UPenn Museum of Archaeology.

Eerkens, J., 2003. Residential Mobility and Pottery Use in the Western Great Basin. Current Anthropology, 44(5), pp.728-738.

Elliott, B., 2015. Facing the Chop: redefining British antler mattocks to consider largerscale maritime networks in the early fifth millennium cal. BC. European Journal of Archaeology, 18(2), pp. 222-244.

Finlay, N. et al., 2019. Calling Time on Oronsay: Revising Settlement Models Around the Mesolithic-Neolithic Transition in Western Scotland, New Evidence from Port Lobh, Colonsay. Proceedings of the Prehistoric Society, 85, pp.1-32.

Gaffney, V., Fitch, S. \& Smith, D., 2009. Europe's lost world, the rediscovery of Doggerland. York: Council for British Archaeology.

Ghesquiére, E., 2012. Le Mesolithique de Basse-Normandie. PhD. Université de Toulouse.

van Gijn, A. \& Little, A., 2016. Tools, use wear and experimentation: extracting plants from stone and bone. In K. Hardy \& L. Kubiak-Martens, eds. Wild Harvest: Plants in the Hominin and Pre-Agrarian Human Worlds. Oxford: Oxbow, pp. 135-150.

Griffiths, S., 2014. Points in Time: The Mesolithic-Neolithic Transition and the Chronology of Late Rod Microliths in Britain. Oxford Journal of Archaeology, 33(3), pp. 221-243.

Hallgren, F., 2009. Tiny Islands in a Far Sea: On the seal hunters of Åland and the northwestern limit in the spread of early pottery. In P. Jordan \& M. Zvelebil, eds. Ceramics Before Farming: The Dispersal of Pottery Among Prehistoric Eurasian HunterGatherers. Walnut Creek, CA: Left Coast Press, pp. 375-393.

Hayden, B., 1995. The emergence of prestige technologies and pottery. In W. Barnett \& J. Hoopes, eds. The Emergence of Pottery. Washington, DC: Smithsonian Institution Press, pp. 257-266. 
Jacobi, R., 1976. Britain Inside and Outside Mesolithic Europe. Proceedings of the Prehistoric Society, 42, pp.67-84.

Jordan, P. \& Zvelebil, M. eds., 2009. Ceramics Before Farming: The Dispersal of Pottery Among Prehistoric Eurasian Hunter-Gatherers, Walnut Creek, CA: Left Coast Press.

Kador, T., 2010. The last of the old: A homogeneous Later Mesolithic Ireland. In B. Finlayson \& G. Warren, eds. Landscapes in Transition. Levant Supplementary Series. Oxford: Oxbow, pp. 147-160.

Kaner, S., 2009. Long Term Innovation: appearance and spread of pottery in the Japanese archipelago. In P. Jordan \& M. Zvelebil, eds. Ceramics Before Farming: The Dispersal of Pottery Among Prehistoric Eurasian Hunter-Gatherers. Walnut Creek, CA: Left Coast Press, pp. 93-120.

Kelly, R., 1995. The Lifeways of Hunter-gatherers: The Foraging Spectrum, Cambridge: Cambridge University Press.

Kuijt, I., 2009. What Do We Really Know about Food Storage, Surplus, and Feasting in Preagricultural Communities? Current anthropology, 50(5), pp.641-644.

Lindqvist, C. \& Possnert, G., 1999. The first seal hunter families on Gotland: on the Mesolithic occupation in the Stora Förvar cave,

Little, A., 2014. Clonava Island revisited: a story of cooking, plants and re-occupation during the Irish Late Mesolithic. Proceedings of the Royal Irish Academy. Section C. Archaeology, Celtic studies, history, linguistics and literature, 114(-1), pp.35-55.

Little, A. \& van Gijn, A., 2017. Enigmatic plant-working tools and the transition to farming in the Rhine Meuse Delta. Excerpta Archaeologica Leidensia II, Analecta Praehistorica Leidensia, 47, pp 1-10.

Lucquin, A. et al., 2018. The impact of environmental change on the use of early pottery by East Asian hunter-gatherers. Proceedings of the National Academy of Sciences of the United States of America, p.201803782.

McGlynn, G., Stuijts, I. \& Stefanini, B. eds., 2018. The Quaternary of the Irish Midlands, Dublin: Irish Quaternary Association.

Mossop, M., 2009. Lakeside developments in County Meath, Ireland: A Late Mesolithic fishing platform and possible mooring at Clowanstown 1. In S. McCartan et al., eds. Mesolithic horizons: Papers presented at the Seventh International Conference on the Mesolithic in Europe, Belfast 2005. Oxford: Oxbow, pp. 895-899.

Olalde, I. et al., 2018. The Beaker phenomenon and the genomic transformation of northwest Europe. Nature, 555(7697), p.543.

Piezonka, H., 2015. Jäger, Fischer, Töpfer: Wildbeutergruppen mit früher Keramik in Nordosteuropa im 6. und 5. Jahrtausend v. Chr, Habelt.

Preston, P. \& Kador, T., 2018. Approaches to Interpreting Mesolithic Mobility and Settlement in Britain and Ireland. Journal of World Prehistory, 31(3), pp.321-345.

Sheridan, A., 2010. The Neolithisation of Britain and Ireland: The "Big Picture." In B. Finlayson \& G. Warren, eds. Landscapes in Transition. Levant Supplementary Series. Oxford: Oxbow, pp. 89-103. 
Skoglund, P. et al., 2014. Genomic diversity and admixture differs for Stone-Age Scandinavian foragers and farmers. Science, 344(6185), pp.747-750.

Sørensen, M., Lübke, H. \& Groß, D., 2018. The Early Mesolithic in Southern Scandinavia and Northern Germany. In N. Milner, C. Conneller, \& B. Taylor, eds. Star Carr Volume I: A Persistent Place in a Changing World. York: White Rose University Press, pp. 305-329.

Spikins, P., 2000. Ethno-facts or ethno-fiction? Searching for the stucture of settlement patterns. In R. Young, ed. Mesolithic Lifeways: Current Research from Britain and Ireland. Leicester: School of Archaeological Studies, pp. 105-118.

Stapel, B. et al., 2012. Neu datierte mesolithische Fundplätze und organische Artefakte aus Westfalen Mesolithikum. Archäologie in Westfalen, 12, pp.27-30.

Sturm, C., Clark, J. \& Barton, L., 2016. The Logic of Ceramic Technology in Marginal Environments: Implications for Mobile Life. American antiquity, 81(4), pp.645-663.

Sturt, F. \& Garrow, D., 2017. Neolithic Stepping Stones: Excavation and Survey within the Western Seaways of Britain 2008-2014, Oxford: Oxbow.

Sturt, F., Garrow, D. \& Bradley, S., 2013. New models of North West European Holocene palaeogeography and inundation. Journal of archaeological science, 40(11), pp.3963-3976.

Taché, K. \& Craig, O., 2015. Cooperative harvesting of aquatic resources and the beginning of pottery production in north-eastern North America. Antiquity, 89(343), pp.177-190.

Tallavaara, M., Eronen, J. \& Luoto, M., 2018. Productivity, biodiversity, and pathogens influence the global hunter-gatherer population density. Proceedings of the National Academy of Sciences of the United States of America, 115(6), pp.1232-1237.

Taniguchi, Y., 2017. The Beginning of Pottery Technology in Japan. In A. Tsuene, O. Nieuwenhuyse, \& S. Campbell, eds. The Emergence of Pottery in Western Asia. Oxford: Oxbow, pp. 155-165.

Taylor, M. et al., 2018. The Wooden Artefacts. In N. Milner, C. Conneller, \& B. Taylor, eds. Star Carr Volume 2: Studies in Technology, Subsistence and Environment. York: White Rose University Press, pp. 367-418.

Vigne, J.-D. et al., 2011. The Early Process of Mammal Domestication in the Near East: New Evidence from the Pre-Neolithic and Pre-Pottery Neolithic in Cyprus. Current anthropology, 52(S4), pp.S255-S271.

Warren, G., 2015. Britain and Ireland inside Mesolithic Europe. In H. AndersonWhymark, D. Garrow, and F. Sturt, eds. Continental Connections: Exploring crosschannel relationships. Oxford: Oxbow Books, pp. 43-58.

Warren, G., In Press. Climate Change and Colonisation of Ireland by hunter-gatherers. Proceedings of the Royal Irish Academy. Archaeology, Culture, History, and Literature, 120.

Whittle, A., Healy, F. \& Bayliss, A., 2011. Gathering Time: Dating the Early Neolithic Enclosures of Southern Britain and Ireland, Oxford: Oxbow.

Woodman, P., 2015. Ireland's First Settlers: Time and the Mesolithic, Oxford: Oxbow. 
Woodman, P., Anderson, E. \& Finlay, N., 1999. Excavations at Ferriter's Cove 19831995. Last Foragers /First Farmers in the Dingle Peninsula, Bray: Wordwell.

Yanshina, O., 2017. The earliest pottery of the eastern part of Asia: Similarities and differences. Quaternary international: the journal of the International Union for Quaternary Research, 441, pp.69-80.

\section{Figure Captions}

Figure 1. Distribution of pottery across Europe at $4500 \mathrm{cal}$. BC. Black = Pottery producing hunter-gatherer groups. Grey = Pottery producing farming groups.

Figure 2. Distribution of T-axes across Europe c. 4500 cal BC.

Figure 3. Cover soil composition maps of Europe (based on LUCAS topsoil data) 